\section{On copyright Copyright in the networked world: interlibrary services}

\author{
Michael Seadle
}

\section{The author}

Michael Seadle is Assistant Director for Systems and Digital Services based at the Michigan State University, East Lansing, Michigan, USA.

\section{Keywords}

Copyright law, Interlending, Canada, Germany,

United States of America

\section{Abstract}

Interlibrary lending and document delivery have become an integral part of the services that contemporary libraries offer. The copyright laws in most countries authorized this copying within reasonable limits, but tensions with publishers may be growing. For interlibrary services to remain effective, libraries must continue to lobby politicians to defend their legal basis. Libraries must also continue to work with publishers to address legitimate economic concerns. This paper looks at the legal basis for interlibrary services, particularly document delivery, in the US, Canadian, and German law.

\section{Electronic access}

The Emerald Research Register for this journal is available at www.emeraldinsight.com/researchregister

The current issue and full text archive of this journal is available at www.emeraldinsight.com/0737-8831.htm
Interlibrary lending and document delivery have become an integral part of the services that contemporary libraries offer. These services mean that libraries do not have to buy every work on a subject of marginal interest, as long as they belong to a network where at least one member owns that work and is willing to share it. The positive image of rich libraries sharing with poorer ones is balanced by publishers' fears of reduced sales. The concern is not merely US or North American. Elmar Mittler of Goettingen University in 1996 wrote that:

Publishers frequently see competition to their own activities in the document delivery services of libraries and other service providers.

When interlibrary lending mainly consisted of sending a physical volume to the requesting library, the potential effect on sales was minimal. Heavily used works like serials were rarely loaned, since no one at the home library could use a work until it came back. As copying technologies improved in the 1960s, it became possible to photocopy a single article rather than send the whole volume. The copyright laws in most countries authorized this copying within reasonable limits, but tensions with publishers may be growing.

New contract language limiting document delivery services for materials from online databases and new court cases in Germany over international lending show two areas where such tensions are evident. Desktop delivery services have not yet, had a legal challenge, but seem potentially vulnerable. This paper looks at the legal basis for interlibrary services, particularly document delivery, in the US, Canadian, and German law.

\section{US Copyright law}

Section 108 of the US copyright law explicitly authorizes document delivery for articles when a user at another library makes a single explicit request:

(d) The rights of reproduction and distribution under this section apply to a copy, made from the collection of a library or archives where the user makes his or her request or from that of another library or archives, of no more than one article or other contribution to a copyrighted collection or periodical issue, or to a copy or phonorecord of a small part of any other copyrighted work. . .

(17 USC 108, 2004).

Received: 20 June 2004

Revised: 20 June 2004

Accepted: 21 June 2004 
But certain conditions must apply, particularly in terms of the ownership and use of the copy:

(1) the copy or phonorecord becomes the property of the user, and the library or archives has had no notice that the copy or phonorecord would be used for any purpose other than private study, scholarship, or research... (17 USC 108, 2004).

The lending library must also display a copyright warning:

(2) the library or archives displays prominently, at the place where orders are accepted, and includes on its order form, a warning of copyright in accordance with requirements that the Register of Copyrights shall prescribe by regulation (17 USC 108, 2004).

Requests for copies of a whole work or the greater part of it are allowed under certain circumstances, if the work is out of print and not available at a "fair" price:

(e) The rights of reproduction and distribution under this section apply to the entire work, or to a substantial part of it, made from the collection of a library or archives where the user makes his or her request or from that of another library or archives, if the library or archives has first determined, on the basis of a reasonable investigation, that a copy or phonorecord of the copyrighted work cannot be obtained at a fair price... (17 USC 108, 2004).

The same requirements for ownership, use, and the display of a copyright warning apply.

The law also explicitly allows the lending of copies of an "audiovisual news program" thanks to an exemption that Senator Howard Baker added to protect the Vanderbilt news archive:

(f) Nothing in this section - ...

(3) shall be construed to limit the reproduction and distribution by lending of a limited number of copies and excerpts by a library or archives of an audiovisual news program, subject to clauses (1), (2), and (3) of subsection (a)... (17 USC 108, 2004).

One of the most important rights that apply is fair use, but this is balanced by a clause that puts contractual obligations before any of the privileges granted in the law:

(f) Nothing in this section - ...

(4) in any way affects the right of fair use as provided by section 107, or any contractual obligations assumed at any time by the library or archives when it obtained a copy or phonorecord of a work in its collections.

This section means that a library's license agreement with the vendor or an article database takes precedence over any interlibrary lending rights in the law. It also means that click-throughlicense contracts can limit software lending, and shrink-wrap-licenses on music CDs or video DVDs can restrict use. Large contracts get fairly careful scrutiny, but click-through and shrink-wrap licenses may provoke little notice and not only may be accepted on behalf of the institution by lower-level staff, but may well be thrown out (in the case of shrink-wrapped) or never recorded (in the case of click-through). It is easy for a library to acquire item-level contractual obligations that could prevent some forms of lending, and be completely unaware of them.

The US law warns strenuously against systematic reproduction that could substitute for subscription or purchase of a work:

(g) The rights of reproduction and distribution under this section... do not extend to cases where the library or archives, or its employee... (2) engages in the systematic reproduction or distribution of single or multiple copies or phonorecords of material described in subsection (d): Provided that nothing in this clause prevents a library or archives from participating in interlibrary arrangements that do not have, as their purpose or effect, that the library or archives receiving such copies or phonorecords for distribution does so in such aggregate quantities as to substitute for a subscription to or purchase of such work (17 USC 108, 2004).

Precisely what constitutes quantities that would substitute for a subscription is not written into the law. In practice many US research libraries pay a royalty via the Copyright Clearance Center for titles used more than five times over the prior five years. This works out to an average of once per year. These royalty costs can be expensive. According to the Copyright Clearance Center (2004), they generally vary from $\$ 1$ to $\$ 14$, and can go higher. Those libraries that charge for document delivery can shift the costs of access from underfunded collections budgets to user fees. Many university libraries do not charge, however, and must absorb the costs in other ways.

New online document delivery request mechanisms make guarding against abuse harder. It is not unusual for a graduate student to search an abstracts database, and then request every article in a journal issue, because it happens to be a theme issue on that topic. Institutional practice in dealing with this kind of request varies, but it seems too obvious like a substitute for buying a copy of that issue for comfort. Yet, the reason for denying such a request can be difficult to explain to users, especially when the request would almost certainly go through if made more slowly, article by article, over several days or weeks, simply because, in a large volume operation, no one would notice.

From a publisher viewpoint, such evasion seems too easy. Users who consistently request articles from a journal that their institution can no longer afford to get on subscription receive the benefit of its intellectual content without having to fight colleagues over subscription priorities. And royalties for selected articles do not necessarily add 
up to a subscription cost. The spiral of increasing subscription prices as fewer and fewer institutions subscribe only forces greater reliance on document delivery. If royalty prices were to escalate in similar fashion, more libraries would be forced to pass the costs through to end-users, who might well resort to asking friends to make copies - bypassing the royalty-payment process. While this would be illegal, it could be hard to detect and stop.

\section{Canadian law}

Interlibrary services function across borders, especially across the US-Canadian border, and of course journals are equally international. Canadian copyright law authorizes document delivery in language relatively similar to that in the US. A user must make an explicit personal request: 30.2 (1) It is not an infringement of copyright for a library, archive or museum or a person acting under its authority to do anything on behalf of any person that the person may do personally under section 29 or 29.1 (Canada, 2003).

As with the US law, Canadian law specifies the purposes for which the request may be made. It also specifies the type of publication:

(2) It is not an infringement of copyright for a library, archive or museum or a person acting under the authority of a library, archive or museum to make, by reprographic reproduction, for any person requesting to use the copy for research or private study, a copy of a work that is, or that is contained in, an article published in (a) a scholarly, scientific or technical periodical; or (b) a newspaper or periodical, other than a scholarly, scientific or technical periodical, if the newspaper or periodical was published more than one year before the copy is made (Canada, 2003).

Certain types of publications are also explicitly excluded:

(3) Paragraph (2)(b) does not apply in respect of a work of fiction or poetry or a dramatic or musical work.

This exclusion corresponds to works that courts generally assume, were written for profit rather than for the advancement of knowledge.

Canadian law sets specific conditions on the copying:

(4) A library, archive or museum may make a copy under subsection (2) only on condition that (a) the person for whom the copy will be made has satisfied the library, archive or museum that the person will not use the copy for a purpose other than research or private study; and (b) the person is provided with a single copy of the work.

The language of the law implies a more active interrogation of the user than may ordinarily take place, otherwise the required purpose strongly resembles the "private study, scholarship, or research" clause in the US law.

Canadian law also has a paragraph explicitly authorizing interlibrary services, but with some additional limitations:

(5) A library, archive or museum or a person acting under the authority of a library, archive or museum may do, on behalf of a person who is a patron of another library, archive or museum, anything under subsection (1) or (2) in relation to printed matter that it is authorized by this section to do on behalf of a person who is one of its patrons, but the copy given to the patron must not be in digital form.

The ban on giving the copy to a patron in digital form restricts the use of a PDF-based desktop delivery service that has grown extremely popular in US research libraries - so popular in fact that, for paper-only publications, some faculty reputedly prefer requesting articles from other libraries, because then they do not have to go to the library, find the volume, and make the photocopy themselves.

The intent of this digital copy restriction is presumably to make it more difficult for the user to distribute the article any further, but the prevalence of low-cost scanners makes that barrier merely a minor annoyance.

\section{German law}

The similarities between the US and Canadian law are not surprising, given their geographic proximity and shared common law tradition. German copyright law belongs to a continental legal system that grew out of Roman law and often makes different assumptions. German interlibrary lending and document delivery services matter for research libraries because Germany remains one of the world's most significant producers (and consumers) of scholarly publications.

The Association of Research Libraries' German-North American Resources Partnership (GNARP, formerly called the German Resources Project), had as one of its earliest missions, the establishment of interlibrary loan and document delivery between the German universities and their North American partners:

The goal of the Document Delivery Working Group is to improve document delivery and interlibrary loan for German-language materials, both among ARL libraries and between German and North American research libraries. GermanNorth American Resources Partnership, 2004

The Working Group's prototype document delivery service used SUBITO e. V., a registered society (eingetragener Verein) whose online service stemmed from an initiative of "the German 
Ministry for Education and Research and the German states...”(SUBITO, 2004).

Unfortunately the prototype service has had to be suspended because of legal issues.

The German copyright law is less explicit about authorizing copying for interlibrary services than the North American laws, but the intent of the language seems similar. Part 1, Section 6, paragraph 52a of the German copyright law authorizes making materials available for teaching (paragraph 1) and research (paragraph 2). The following is my translation:

1. Making available small parts of a published work, or works of limited extent such as single articles from a newspaper or journal, for use as part of instruction in schools, institutions of higher education, or non-commercial establishments for vocational training, is permitted for a specifically limited group of participants in so far as necessary for these purposes, and not for the pursuit of commercial goals.

2. Making available published parts of a work or a work of limited extent such as single articles from newspapers or journals, exclusively for a limited group of persons for their own scholarly research, is permitted in so far as necessary for these purposes, and not for the pursuit of commercial goals (Germany, Federal Republic, 2003).

Materials explicitly created for use in classroom teaching are excluded, and the use of film is allowed after an appropriate waiting period:

(2) Making a work available that was specifically for use in teaching is permissible only with the consent of the rights holder. Making a film publicly available before the passage of two years after its appearance in theaters in the region where this law applies is permissible only with the consent of the rights holder.

The copying necessary to these permissions is also explicitly authorized:

(3) The duplication required for making works available in accordance with section (1) is permitted.

But this copying is not royalty free, and it requires the use of the German equivalent of the Copyright Clearance Center.

(4) A reasonable amount must be paid for making works available in accordance with paragraph 1 .

The payment must be handled through a collecting society.

At present (June, 2004) a legal challenge against SUBITO is underway that appears to attack, not the legal basis of the international document delivery service, but the costs mentioned in the section above:

The trade association of the German book dealers has stopped the Berlin-based SUBITO document delivery service. The background has to do with a controversy over sending digital extracts from books and articles abroad. But the core of the issue turns on the size of royalties for books and magazines in this digital age. Thus, providing electronic services will become significantly more expensive and complex. Subito chairman Uwe Rosemann fears this will torpedo document delivery to researchers. Modern remote lending could be threatened. - Heise Online, 2004

While negotiations are underway to address the challenge to SUBITO, this suit represents only one instance of the problem of maintaining an economic balance that does justice to both interests of publishers and libraries and their users. A similar legal challenge could occur anywhere if publishers begin to feel that document delivery has become a substitute for subscriptions.

\section{Conclusion}

Interlibrary lending and particularly document delivery have been one of the success stories of library collaboration in recent decades. The demand for these services is growing and their quality has improved greatly because of the use of digital techniques and Internet-based delivery. They do a great deal to equalize resources among institutions, and generally help students to get the materials they need at little or no cost.

Publishers have not resisted the growth of interlibrary services, partly because of the strong legal basis for them, partly because of the compensation they receive. But the more digital the process becomes, the more publishers worry about the specter of a KaZaA-style free exchange that bypasses the royalty process. While some publishers have tried to write contract language to restrict the use of articles in online databases for interlibrary lending, many universities resist such provisions.

The current balance of interlibrary services and royalty payments represent only one of many possible economic models. Large-scale consortial deals for access to article databases effectively eliminates the need for document delivery for those works among those institutions, though it does so at a high cost to libraries and often with the inclusion of unwanted titles. It is not clear that such a model would scale well to meet the demands of scholars.

For interlibrary services to remain effective, libraries must continue to lobby politicians to defend their legal basis. Libraries must also continue to work with publishers to address legitimate economic concerns. The current system works far too well not to continue to defend it. 
Copyright in the networked world: interlibrary services

Michael Seadle

\section{References}

17 USC 108 (2004), United States Code, Title 17, Chapter 1, Section 108, available at: www.copyright.gov/title17/ 92chap1.html\#108 (accessed June 2004).

Canada (2003), Consolidates Statutes and Regulations, Copyright Act, available at: http://laws.justice.gc.ca/en/ C-42/39062.html\#rid-39082 (accessed June 2004).

Copyright Clearance Center (2004), "Transactional reporting service: frequently asked questions", available at: www.copyright.com/Help/HelpTrsFAQ.asp\#2 (accessed June 2004).

German-North American Resources Partnership (2004),

"Document delivery working group", available at: http:// grp.lib.msu.edu/docdelivery.html (accessed June 2004).

Germany, Federal Republic (2003), "Federal Laws, Copyright Law [Urhebergesetz], Paragraph 52a", My Translation,
Library Hi Tech

Volume $22 \cdot$ Number $3 \cdot 2004 \cdot 328-332$

available at: http://bundesrecht.juris.de/bundesrecht/urhg/ 52a.html (accessed June 2004).

Heise Online (2004), "The book trade lobby goes against libraries because of document delivery", My Translation, available at: www.heise.de/newsticker/meldung/48024 (accessed June 2004).

SUBITO (2004), "What it SUBITO?", available at: www.subitodoc.com/ (accessed June 2004).

\section{Further reading}

Mittler, E. and Ecker, R. (1996), "European copyright user platform: ECUP and ECUP+", Bibliotheksdienst Heft 8/9, 96. My Translation, available at: http://deposit.ddb.de/ep/ netpub/89/96/96/967969689/_data_stat/www.dbi-berlin. de/dbi_pub/bd_art/96_08_08.htm (accessed June 2004). 